1989

\title{
The Response of Estuarine Circulation to Local Wind Events
}

K. P. Kiley

Virginia Institute of Marine Science

C. S. Welch

Virginia Institute of Marine Science

Follow this and additional works at: https://scholarworks.wm.edu/vimsbooks

Part of the Oceanography Commons

\section{Recommended Citation}

Kiley, K. P. and Welch, C. S., "The Response of Estuarine Circulation to Local Wind Events" (1989). VIMS Books and Book Chapters. 32.

https://scholarworks.wm.edu/vimsbooks/32

This Book Chapter is brought to you for free and open access by the Virginia Institute of Marine Science at W\&M ScholarWorks. It has been accepted for inclusion in VIMS Books and Book Chapters by an authorized administrator of W\&M ScholarWorks. For more information, please contact scholarworks@wm.edu. 


\section{Estuarine}

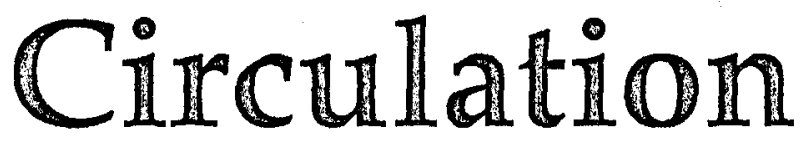

Edited by

\section{Bruce J. Neilson, Albert Kuo, and John Brubaker}

School of Marine Science

The College of William and Mary in Virginia,

Gloucester Point, Virginia

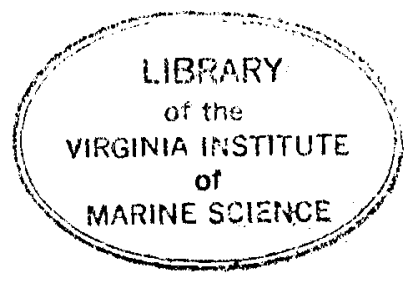

\section{Humana Press • Clifton, New Jersey}


(c) Copyright 1989 by The Humana Press Inc.

Crescent Manor

PO Box 2148

Clifton, NJ 07015

All rights of any nature whatsoever reserved.

No part of this book may be reproduced, stored in a retrieval system, or transmitted in any form or by any means, including electronic, mechanical, photocopying, microfilming, recording, computer database entry, or networking, or in any manner whatsoever without written permission from the publisher.

\section{Llbrary of Congress Cataloging-In-Publication Data}

Estuarine circulation.

(Contemporary issues in science and society) Includes index.

1. Estuarine oceanography. 2. Ocean circulation.

I. Neilson, Bruce J. II. Brubaker, John. III. Kuo, Albert. IV. Series.

GC97.E775 $1989 \quad 551.46$ '09 89-1725

ISBN 0-89603-155-1 


\section{Preface}

Estuaries exist along the edge of the oceans and seas, and are characterized by the dilution of sea water by inflowing fresher waters. The motion and interaction of these two types of water (fresh and salt water) determine the salinity distribution within the estuary and that, in turn, affects the organisms residing there. The purpose of this volume is to review the status of our understanding of estuarine circulation and how the circulation patterns affect living and nonliving resources in estuaries.

For many years, the primary paradigm for estuarine circulation was the two-layered net or nontidal gravitational circulation pattern first proposed by Dr. Donald Pritchard in his studies of the James River estuary. During the last decade or so, research has focused on the many variations about this theme and the factors that control the transport processes. Many of these aspects are covered in the initial papers in this volume. Water movement, of course, is of interest because it transports marine organisms, sediments, and pollutants. Estuarine circulation has a significant effect on estuarine food chains, and on the distribution and abundance of organisms, such as the American oyster, that are freely transported by the currents during larval stages. The intent is to bring together many of these topics in a single volume.

This volume is dedicated to Dr. Donald W. Pritchard, our colleague and friend, as was the conference held in Gloucester Point in January of 1985. The conference was organized as one means of recognizing his contributions to our understanding of the physical oceanography of estuaries. It was held in conjunction with the 1985 Charter Day exercises of the The College of William and Mary. At that time, Dr. Pritchard was awarded an honorary degree of Doctor of Science.

The editors would like to thank those who atttended the conference and especially those who made presentations, the authors of the 
$v i$

papers included in this volume, the many persons who reviewed these papers, and Mrs. Barbara Cauthorn, who prepared the final versions of the manuscripts.

Bruce J. Neilson

Albert Kuo

John Brubaker 


\title{
Contents
}

\author{
$v \quad$ Preface \\ vii Contents \\ ix Contributors
}

1 Estuarine Classification-A Help or a Hindrance, Donald W. Pritchard

39 Estuarine Flow Interaction with Topography; Lateral and Longitudinal Effects, K. R. Dyer

61 Headland Eddies in a Tidal Estuary, Nungjane C. Shi and Lawrence H. Larsen

87 Residual Currents in the Peconic Bays Estuary, Robert E. Wilson and Mario E. C. Vieira

97 The Response of Estuarine Circulation to Local Wind Events, K. P. Kiley and C.S. Welch

113 Computer Simulation of Wind-Driven Circulation in a Coastal Lagoon, Ned P. Smith

133 On Inter-Tidal Transport Equation, Ralph T. Cheng, Shizuo Feng, and Pangen $\mathrm{Xi}$

157 Excitation-Response Analysis of Estuarine Circulation, John M. Hamrick

183 A Tale of Two Estuaries: Columbia Bay, Alaska, and San Francisco Bay, California, Roy A. Walters

201 Time Scale Variations of Estuarine Stratification Parameters and Impact on the Food Chains of the Chesapeake Bay, Mary Altalo Tyler and H. H. Seliger 
235 The Influence of Physical Factors in Governing Temporal and Spatial Variations of Seston, Joseph A. Berg and Roger I. E. Newell

255 Interaction Between Circulation of the Estuary of the James River and Transport of Oyster Larvae, Evon P. Ruzecki and William J. Hargis, Jr.

279 The Role of Bottom Current and Estuarine Geomorphology on the Sedimentation Processes and Productivity of Wreck Shoal, an Oyster Reef of the James River, Virginia, Joseph T. DeAlteris

309 Considerations on Soft Mud Response under Waves, Peng-Yea Maa and Ashish J. Mehta

337 River Discharge and Sediment Deposition in the Upper Pamlico Estuary, Jonathan D. Phillips

351 Role of Models in Estuarine Flow and Water Quality Analysis, Tavit O. Najarian and Donald R. F. Harleman

375 Index 
THE RESPONSE OF ESTUARINE CIRCULATION TO LOCAL WIND EVENTS

K. P. Kiley and C. S. Welch

Virginia Institute of Marine Science

School of Marine Science/Co1lege of William and Mary

Gloucester Point, Virginia 23062

\section{ABSTRACT}

An analysis of non-tidal estuarine circulation and loca1 wind events was conducted employing wind and current records taken along the York River. Three distinct response conditions of non-tidal circulation to wind were observed. These conditions exhibited significant temporal and spatial variability. The first was typified by a positive two layer flow response to wind that was significant in the middle section of the York during the first six days of the study. The second exhibited a positive one layer flow response to wind that was significant in the upper section of the York during the last three days of the study. The third exhibited no statistically significant relation between current patterns and wind. This condition occurred near the mouth of the estuary, and it may indicate that the currents near the mouth respond more substantial1y to conditions in the adjacent Che sapeake Bay than to those caused by local winds.

\section{INTRODUCTION}

The present study has several features of interest. A current meter data set was examined that had relatively high spatial resolution, particularly in the vertical coordinate. A prediction-subtraction method of tidal 
current elimination was employed which resulted in preservation of non-tidal currents in the intra-tidal and higher frequency ranges. An epochal analysis approach, based on periods of relatively constant winds, was used as a broadband method of synchronously demodulating the specific effects of winds. These features facilitated the examination of the horizontal and vertical structure of the circulation response in the York to wind events on the order of a tidal cycle.

With regards to circulation, wind stress is the major cause of the eddy flux of momentum across the air-water interface in coastal plain estuaries (Pritchard, 1956; Hansen \& Rattray, 1965; Dyer, 1973 Officer, 1976; Wang, 1979). The role of wind stress has been formulated by Hansen \& Rattray (1965) and Officer (1976) as part of a steady state model of estuarine circulation, in which net flow is equa1 to fresh water discharge. The vertica 1 profile of wind induced flow is parabolic in form, with surface and upper layer flow in the direction of wind, lower layer flow in the opposite direction, and no flow at the bottom. Studies by Weisberg (1976) and Farmer \& Osborn (1976) support the general concept of wind induced flow formulated by Hansen \& Rattray (1965). Weisberg's study demonstrated a significant bottam compensating flow (on the order of $2-3 \%$ of the wind speed) in response to axial (along the estuary axis) winds. Farmer \& osborn's study revealed a significant, positive relation between the near surface current and the local axial wind, and no significant relation, as expected, between the mid-depth current and the axial wind.

E11iott (1976) observed two significant modes of response of non-tida1 currents (diurnal or greater) to meterological forcing based on year-long surface, middepth, and bottom current measurements taken at one station in the Potomac River. The first response mode was related to local axial winds. Subtidal currents displayed a two layer flow similar to that formulated by Hansen \& Rattray (1965). Changes in mean water level and surface slope along the estuary were positively related to local winds. The second response mode was not well related to local axial winds or surface slope along the estuary. On 1 y $50 \%$ of the fluctuations in the estuarine data could be explained by local wind forcing. Elliott proposed that 
une $x$ 1ained fluctuations might be due to interactions between the Potomac and the Chesapeake Bay.

Wang \& Elliott (1978) concluded that the short term (2 days or less) response of the Potomac to winds was characterized by two layer flow induced by local winds, and that the long term response was significantly related to Ekman flux at the estuary mouth. For the western tributaries of the Chesapeake Bay, Ekman flux acts in opposition to (so as to balance) the local wind induced flow.

In a study of non-tidal currents (diurnal or greater) in the Chesapeake Bay, Wang (1979) found evidence of a spatial transition from one layer flow in the lower bay to two layer flow in the upper bay, the latter flow being induced by local axial winds. The current data consisted of two month observations taken at one-third and two-thirds depth at a lower and upper bay station. Results indicated large exchanges of water between the Chesapeake Bay and the coastal ocean that were coherent and in-phase with the axia1 (north-south) wind for periods of $2-3$ days and outof-phase for longer periods. Establishment of one or two layer wind induced flow was also related to vertical eddy viscosity, with two layer flow associated with strong stratification and one layer flow associated with weak stratification.

Current observations in the above studies were taken over varying lengths of time, at one to three depths, at one or two stations along each estuary. The non-local nature of the estuarine response to meterological forcing observed in the Potomac and the different responses of current to wind observed in the lower and upper Chesapeake Bay indicate that the temporal and spatial resolution of estuarine observations greatly influence the resulting conclusions regarding circulation. With the exception of Farmer \& Osborn (1976), current records in the above studies were low-pass filtered to remove the effects of the semidiurnal and diurnal tidal currents, thus precluding examination of correspondingly short term wind and current relationships. The studies of the Potomac and Chesapeake Bay indicate that basin geometry and physical factors, such as stratification, may significantly alter the modes of flow in response to induced forces. The 
present study, while severely truncated in temporal duration, does have greater vertical and horizontal spatial resolution than the studies reviewed above.

\section{FIELD STUDY}

The York River is a coastal plain estuary located on the southwestern shore of Chesapeake Bay. It is tidal throughout its extent. The form of the tidal wave in the York is primarily progressive (Hicks, 1964), with maximum reported tidal currents of about $0.6 \mathrm{~ms}^{-1}$ (NOS, 1972). At the head of the York, the watershed splits into two further branches, the Mattaponi and the Pumunkey Rivers, each of which possess substantia1 tida1 prisms in their meandering courses. During the study period, the York was partially stratifiod with surface salinities varying from 4 ppt at the head to 16 ppt at the mouth. Bottom salinities were typically $2-4$ ppt greater than those of the surface (Kiley, 1980).

This study focuses on the rosponse of currents to rolatively short-term (7-46 hours) winds, and examines the spatial variability of that response within an estuary. During 10-20 April 1973 currents wero measured at $3 \mathrm{~m} \mathrm{in-}$ tervals from surface to bottom at 11 locations along the York (Figure 1). Although the original study was not designed for the observation of wind and current interaction, the data set provided an opportunity to examine this feature. Stations $\mathrm{Y}_{2-1}$ and $\mathrm{Y}_{4-2}$ were were samplod from 10-20 April, the remaining current meter stations in the middle and lower York were sampled from 10-16 April, while those in the upper York wero sampled from 16-20 Apri1. Braincon histogram film recording current meters were used. The current data were reduced as doscribed by Jacobson (1973), resulting in 20 minute samples of current velocity. From the 43 current meter locations originally sampled, 28 useable records were obtained, the rest (15), including a 11 records at station $\mathrm{Y4}-1$, were lost due to equipment failure or damage.

Wind data consistod of continuous wind velocity measurements reduced to hourly averages. The data were collected at the Gloucester Point campus of the Virginia Institute of Marine Science (VIMS, Kiley, 1980). 


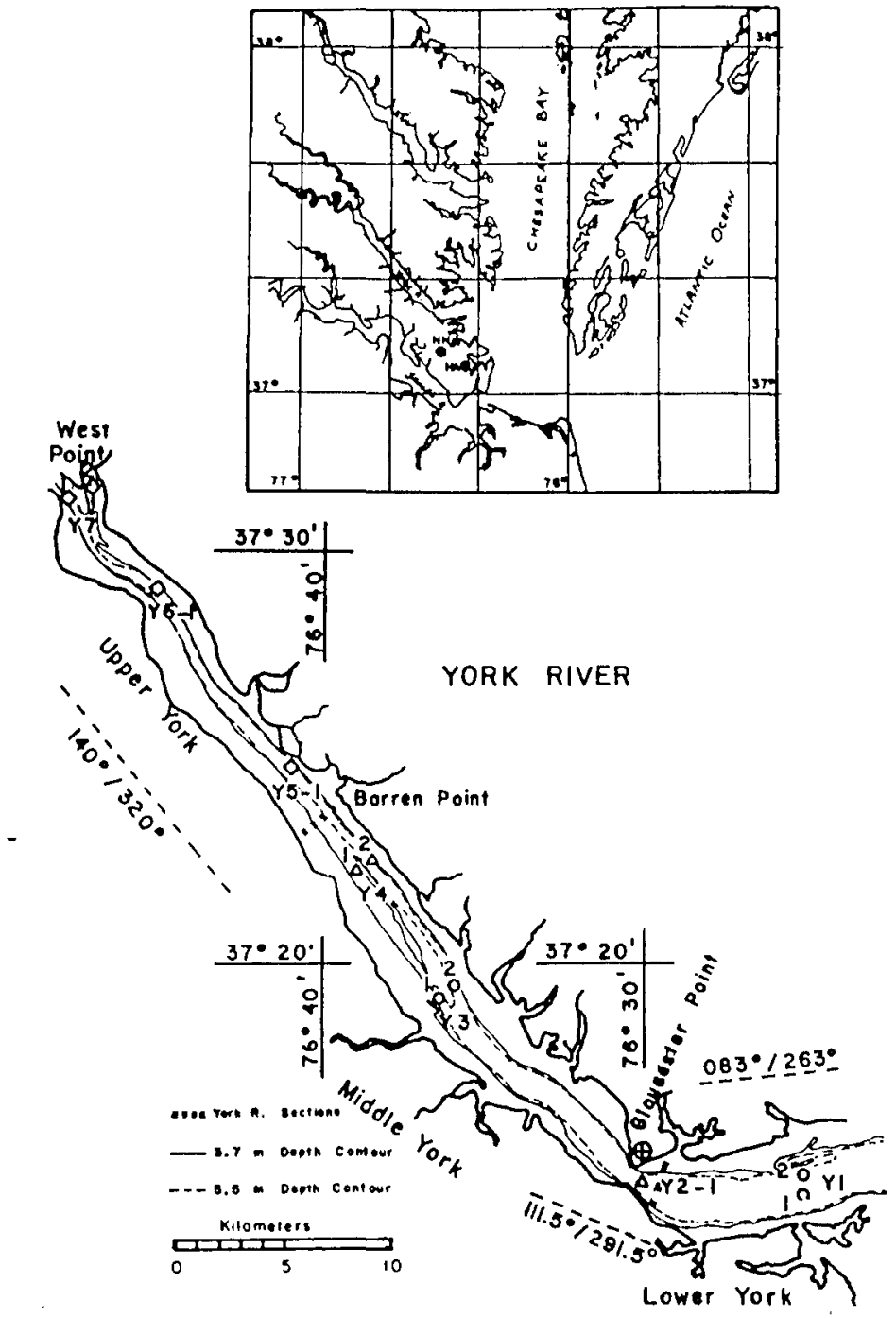

Figure 1. York River Study Area Including Current Meter Sampling Sites and Local Wind Stations.

A. Current Meter Stations

O Samplod 10-16 Apri1 1973

$\triangle$ Sampled 10-20 Apri1 1973

$\diamond$ Sampled 16-20 April 1973

B. $\oplus$ Wind Station 


\section{DATA ANALYSIS}

The wind and current vector time series wero reduced to axial components. A prediction-subtraction method of tidal current elimination was then employed. The mean and linear trend in the axial wind and current records were removed by the mothod of least squares. Semidiurnal and higher frequency tidal components were ostimated from the reduced current time series by harmonic analysis (Dronkers, 1964, Boon and $\mathrm{xiley,} \mathrm{1978),} \mathrm{and} \mathrm{then} \mathrm{sub-}$ tracted from the current time series, resulting in detrended non-tidal current records (Figure 2a-e).

Intial analysis of the axial wind data identified 12 epochs of steady values (Figuro 3). An epochal method was omployed to oxamine responses that were ropresentative of tho steady state adjustments of current to wind. Mean values of the detrended axial components of wind and nontidal current observations were calculated for each wind epoch. An analysis of variance was performed on the current records to test the significance of the differences between the mean current values for each epoch. Profiles of the mean current values were constructed and evaluated (Figures 4). The degree of association between wind and current was detormined by correlation and regression analysis of wind and current values for each epoch. (Figure $2 \mathrm{~g}$. )

\section{RESULTS}

The least squares analysis of current over time revealed that all but two stations at the head of the estuary ( $Y 7-1$ and $Y 7-2$ ) exhibited characteristics of two layer gravitational estuarine circulation (Tablo 1 ). Stations at the head of the estuary had net downstrean flow at all levels, indicating dominance of river flow over gravitational circulation. At the lower York transect the lovel of no-net-flow is tilted, deeper at the southern station than at the northern station. Overall, the classic two layer gravitational circulation pattern associated with a partially mixed estuary was observed.

Results of analysis of variance of the detrended nontidal axial curront records indicated that $80 \%$ of the variation in each record occurred within wind epochs as 

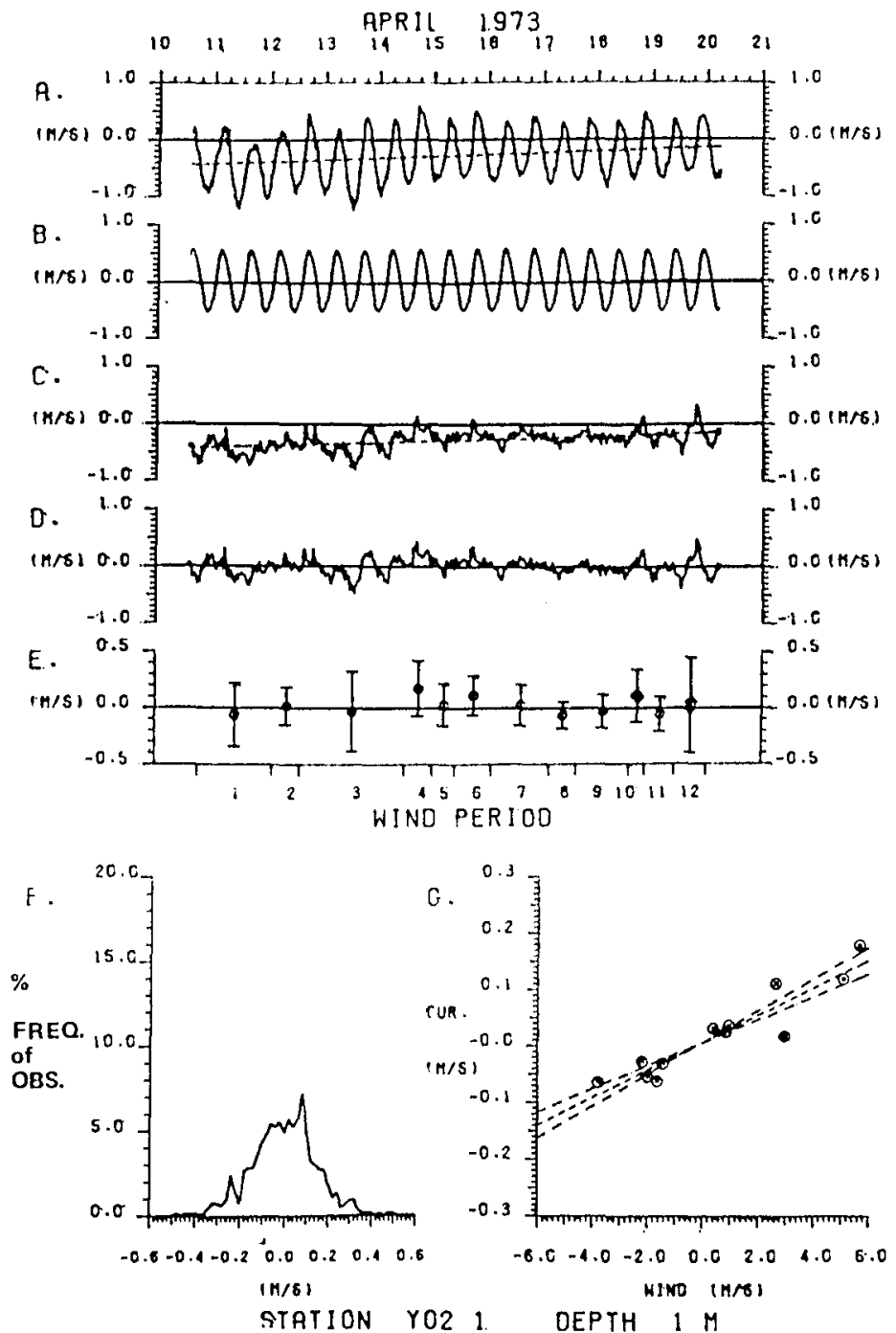

Fis.2. Time Serios Plot of Axial Component of Current. STRTION YO2

Velocity, Histogram of Current Velocity, \& Scettor

Dlagram of Wind \& Curront Volocity for Station Y2-1

A. Observed Current

B. Hermonic Analysis Estimato of Tidal Current

C. Non-Tidal Corrent

D. Dotrondod Non-Tidal Curront

E. Avg Dotronded Curront Volocity During Each Wind Epoch

F. Histogran of Detronded Non-Tidal Current Velocity

G. Scatter Diagram of Avorazo Values of Dotrendod Find and Dotrondod Non-tidal Current for Each Wind Epoch 

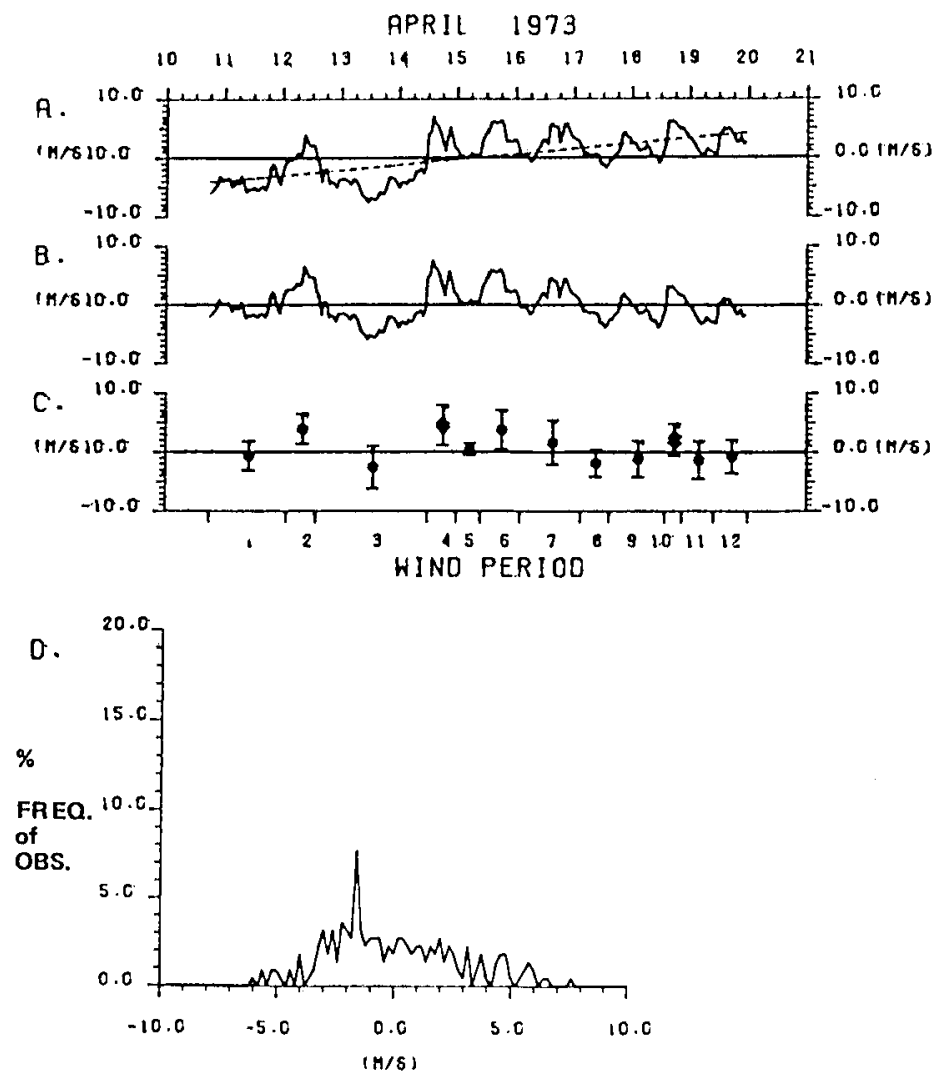
WIND STATION
Axis $140.0^{\circ}$

Figure 3. Time Series Plot of Arial Component of Wind Velocity and Histogram of Wind Volocity.
A. Observed Wind
B. Detronded Observod Find
C. Avg Detronded Wind Velocity During Each Wind Epoch
D. Histogram of Detrended Wind Velocity 


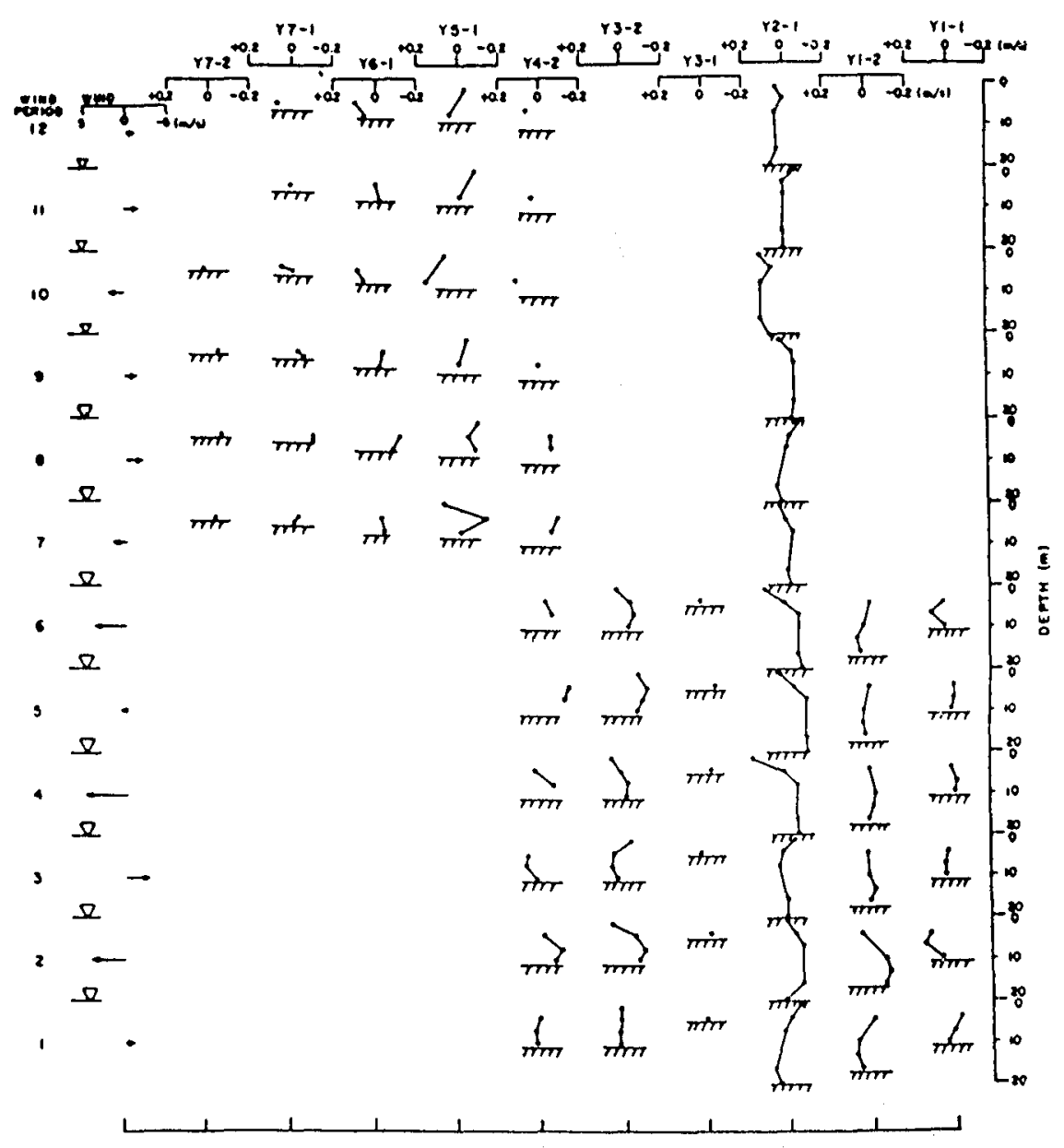

Figure 4. Axial Profiles of Average Detrended Non-Tidal Currents for Each Wind Epoch

(positive - apstream, negative - downstream) 
TABLE 1

Average Axial Currents During Study Period and Correlation and Regression Coefficients for Wind Epochs $1-12$ (positive - upstream, negative - downstream)

\begin{tabular}{|c|c|c|c|c|c|}
\hline Station & $\begin{array}{c}\text { Depth } \\
\text { (m) }\end{array}$ & $\begin{array}{c}\text { Ave rage } \\
(\mathrm{m} / \mathrm{s})\end{array}$ & $\begin{array}{l}\text { Corr. } \\
\text { Coef. }\end{array}$ & $\begin{array}{l}\text { Signf. } \\
\text { Leve1 }\end{array}$ & $\begin{array}{l}\text { Regres } \\
\text { Slope }\end{array}$ \\
\hline $\begin{array}{c}\mathrm{Y} 1-1 \\
" 1\end{array}$ & $\begin{array}{r}4 \\
7 \\
10\end{array}$ & $\begin{array}{r}-0.115 \\
-0.007 \\
0.032\end{array}$ & $\begin{array}{r}0.420 \\
0.344 \\
-0.288\end{array}$ & $\begin{array}{l}0.56 \\
0.46 \\
0.40\end{array}$ & $\begin{array}{r}0.012 \\
0.013 \\
-0.004\end{array}$ \\
\hline $\begin{array}{c}Y 1-2 \\
11 \\
11 \\
11\end{array}$ & $\begin{array}{r}4 \\
10 \\
13 \\
16\end{array}$ & $\begin{array}{r}-0.006 \\
0.080 \\
0.082 \\
0.061\end{array}$ & $\begin{array}{l}-0.092 \\
-0.509 \\
-0.232 \\
-0.305\end{array}$ & $\begin{array}{l}0.12 \\
0.67 \\
0.31 \\
0.41\end{array}$ & $\begin{array}{l}-0.001 \\
-0.015 \\
-0.009 \\
-0.009\end{array}$ \\
\hline $\begin{array}{l}Y 2-1 \\
11 \\
11 \\
11 \\
" 1\end{array}$ & $\begin{array}{r}1 \\
4 \\
7 \\
16 \\
21\end{array}$ & $\begin{array}{r}-0.279 \\
-0.125 \\
-0.016 \\
0.126 \\
0.162\end{array}$ & $\begin{array}{r}0.939 \\
0.085 \\
-0.519 \\
-0.613 \\
-0.560\end{array}$ & $\begin{array}{l}0.99 \\
0.20 \\
0.92 \\
0.97 \\
0.94\end{array}$ & $\begin{array}{r}0.024 \\
0.001 \\
-0.009 \\
-0.012 \\
-0.009\end{array}$ \\
\hline Y3-1 & 4 & 0.034 & -0.839 & 0.97 & -0.008 \\
\hline $\begin{array}{c}\text { Y3-2 } \\
11 \\
11 \\
"\end{array}$ & $\begin{array}{r}1 \\
4 \\
7 \\
10\end{array}$ & $\begin{array}{c}-0.292 \\
-0.116 \\
0.012 \\
0.050\end{array}$ & $\begin{array}{r}0.827 \\
-0.492 \\
-0.754 \\
-0.755\end{array}$ & $\begin{array}{l}0.96 \\
0.64 \\
0.91 \\
0.91\end{array}$ & $\begin{array}{r}0.011 \\
-0.009 \\
-0.017 \\
-0.013\end{array}$ \\
\hline $\begin{array}{c}\text { Y4-2 } \\
" 1 \\
"\end{array}$ & $\begin{array}{r}4 \\
7 \\
10\end{array}$ & $\begin{array}{r}-0.059 \\
0.103 \\
0.130\end{array}$ & $\begin{array}{l}-0.390 \\
-0.652 \\
-0.939\end{array}$ & $\begin{array}{l}0.64 \\
0.99 \\
\text { N/A }\end{array}$ & $\begin{array}{l}-0.009 \\
-0.018 \\
-0.015\end{array}$ \\
\hline $\begin{array}{l}\text { Y5-1 } \\
\text { " } \\
" 1\end{array}$ & $\begin{array}{l}1 \\
4 \\
7\end{array}$ & $\begin{array}{r}-0.074 \\
0.038 \\
0.111\end{array}$ & $\begin{array}{l}0.934 \\
\mathrm{~N} / \mathrm{A} \\
0.782\end{array}$ & 0.99 & 0.035 \\
\hline $\begin{array}{c}\text { Y6-1 } \\
\text { "I }\end{array}$ & $\begin{array}{l}4 \\
7\end{array}$ & $\begin{array}{l}0.004 \\
0.061\end{array}$ & $\begin{array}{l}0.625 \\
0.587\end{array}$ & $\begin{array}{l}0.79 \\
0.75\end{array}$ & $\begin{array}{l}0.030 \\
0.020\end{array}$ \\
\hline $\begin{array}{c}Y 7-1 \\
" 1\end{array}$ & $\begin{array}{l}4 \\
5\end{array}$ & $\begin{array}{l}-0.015 \\
-0.062\end{array}$ & $\begin{array}{l}0.566 \\
0.938\end{array}$ & $\begin{array}{l}0.67 \\
0.65\end{array}$ & $\begin{array}{l}0.021 \\
0.018\end{array}$ \\
\hline Y7-2 & 4 & -0.095 & 0.892 & 0.62 & 0.011 \\
\hline
\end{tabular}


opposed to between. The mean current values of the epochs were, however, all statistically different, based on an Fdistribution value at the $95 \%$ confidence level. These results suggested that a significant wind and current relationship was observed in the York for periods of steady axial winds.

Three distinct response conditions of current to wind were observed. Near the mouth of the York (Figure 5), the non-tidal current variability was not strongly related to local winds. In the middle section of the estuary (transects 2 through 4) the two 1ayer, parabolic flow response proposed by Hansen \& Rattray (1965), was observed, while in the upper section of the estuary (transects 5 through 7 ) the flow response, particularly in the bottom part of the water column, was significant and in the direction of the wind.

From the study data, 1 ittle can be concluded about the effect of wind on currents in the lowest portion of the York. At and above the constriction and axis shift at Gloncester Point, the two layer wind induced circulation pattern was observed with a near-surface (1 m) speed between 1.4 and 2.4 percent of the wind component in the same direction and a lower layer maximum between 0.9 and 1.7 percent of the wind speed in the direction opposite to the wind. The layer of no net wind-driven motion was somewhat above the one third depth level of the parabolic theory and the current extrapolated to the bottan depth does not reach zero. This suggested that the wind-driven current passed through a laminar boundary layer very near the bottom. The appearance of a net transport opposite to the wind may be misleading because of the greater width of the estuary near the surface than in the channel depths.

In the upper part of the York, all of the axial residual currents were in the direction of the wind, at speeds between 1.1 and 3.6 percent of the wind velocity component. Because this response cannot have zero transport, it was clearly not a steady-state response and may have been a reflection of the substantial storage volume available in the branching, meandering $r$ ivers above the York. The high rate of the current near the bottom again suggests the presence of a laminar sublayer at the bottom of the water column. 

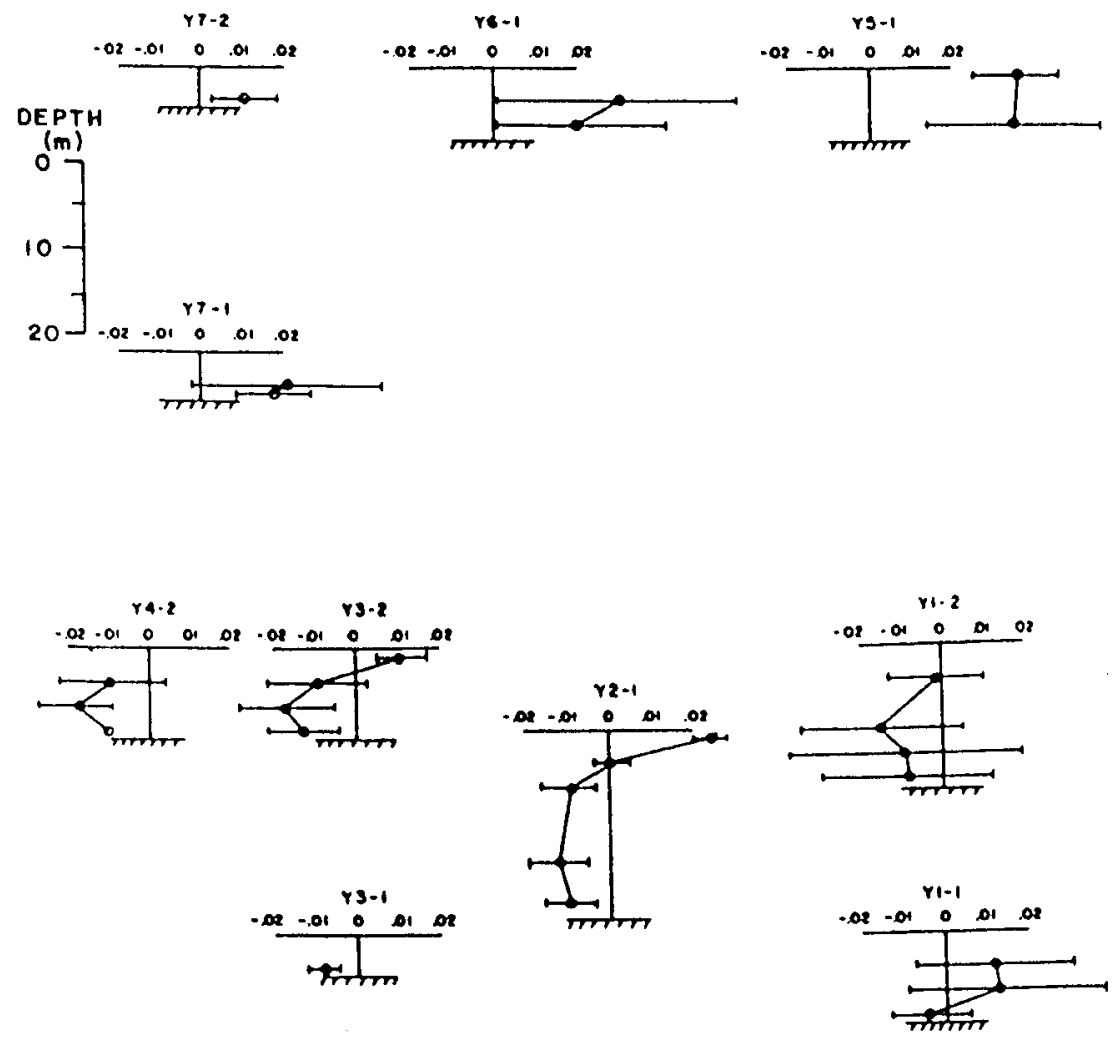

Figure 5. Average Current Dependence on Wind Speed During Study. (error bars represent 80 percent significance values) 
The responses noted above for the middle and upper York were spatially and temporally separated, due to the overall sampling scheme (Figure 4). In order to determine whether the spatial or the temporal separation was the more important, two stations which were maintained for the duration of the study (Y2-1 and $\mathrm{Y} 4-2)$, were reanalyzed for each time segment separately (Figure 6). The station at the transition between the middle and lower part of the estuary (Y2-1) showed some indication of a transition to a unidirectional wind response in the latter part of the study, but the results are not clear, because the 80 percent significance limits at all levels showed substantial overlap between the two time segments. At station Y4-2 there was a clear demarcation between the two periods, the record at $7 \mathrm{~m}$, the sole survivor of the second period, clearly changed sign between the subperiods from opposite to wind, indicative of the lower layer in a two layer pattern, to with wind. The evidence from the subsamples, then, is that at least part of the difference in wind response between stations in the middle and upper parts of the York was temporal in nature.

\section{DISCUSSION}

The non-tidal wind driven currents observed in this study conform, for the most part, to the two layer, zero net, wind driven flow proposed by Hansen \& Rattray (1965). This is especia11y the case for the station at the estuary's major constriction (Station Y2-1) where the axia1 components of flow would most likely be greater than the 1ateral components. The York, as any estuary, is not a closed system and the responses for some of the wind epochs seem to indicate a net landward or seaward wind induced flow. A one layer flow response appears in the upestuary stations, in contrast with the two layer flow response proposed by Wang (1979) for the upper bay. This response is not in keping with a steady state response of current to wind, and may be due to a number of factors: failure to achieve steady state locally due to the relatively short time frame of the chosen wind epochs, volume flux between the York and adjacent water bodies, or a $r$ tifacts of diurnal inequalities or other low frequency tida1 effects remaining in the current data. Analysis of tidal height records would reveal the significance of the volume flux in the estuary during the study period and 

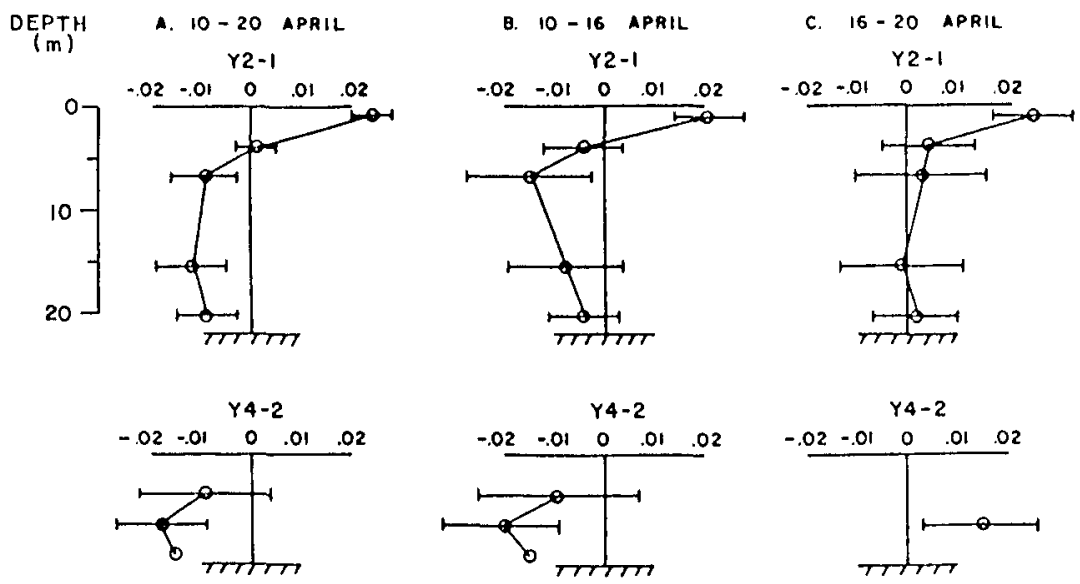

Figure 6. Current Profiles at Stations Maintained Throughout the Study Analyzed for:

A. The Entire Study

B. The Period of 10-16 April

C. The Period of 16-20 Apri1

might explain the one layer flow observed during the second part of the study.

\section{CONCLUSIONS}

The present study indicates that both a two layer response of current to wind, as given by Hansen \& Rattray (1965), and a one layer response, suggestive of an openended channe1, occur in the York. These responses are established in time periods of as 1 ittle as 12 hours, periods frequently filtered out of longer term data. Conservation of mass considerations require that the one layer response cannot be representative both of the estuary cross-section and of time mean values. In order to determine the regimes over which a one layer response is applicable, even for an estuary of such simple geometry as the York, longer records are required over more dense horizontal grids across a transect. The vertical spacing $(3 \mathrm{~m})$ seems sufficient for the determination of the vertical profile, at least in depths of $15 \mathrm{~m}$ or more. If a 
zero bottom velocity is required for the wind-driven component, a bottom boundary layer is implied by these data; complete determination of the profile would require a dense sampling scheme near the bottom. The importance of surface height data as a function of time during a current meter survey is also suggested by the present study, for it would permit an estimate of time varying water storage in bounding areas and allow volume budget calculations to be performed.

\section{ACKNOWLEDGEMENTS}

Current data was collected by VIMS as part of a contract with the United States Army Corps of Engineers (Contract No. DACW31-70-C-0079). Wind data was collected by VIMS. We would like to express our thanks to the Institute for support and use of the wind data and to the Corps for use of the current data.

\section{REFERENCES}

Boon, J. D. III and Kiley, K. P. 1978 Harmonic Analysis and Tida1 Prediction using the Method of Least Squares. VIMS Spec. Rept. in App1. Mar. Sci. and Ocean Eng., No. $186,49 \mathrm{p}$.

Dronkers, J. J. 1964 Tidal Computations in Rivers and Coastal Faters. North Holland Publishing Co., New York, $518 \mathrm{p}$.

Dyer, K. R. 1973 Estuaries: A Physical Introduction. John Wiley and Sons, Inc., New York, $140 \mathrm{p}$.

E11iott, A. J. 1976 A Study of the Effect of Meterological Forcing on the Circulation of the Potomac Estuary. Chesapeake Bay Institute, Special Report 56, Ref. 76-9, $32 \mathrm{p}$.

Farmer, D. M. 1976 The Influence of Wind on the Surface Layer of a Stratified Inlet: Part 2: Analysis. J. Phys. Oceanogr. 6, 941-952.

Farmer, D. M. \& Osborn, T. R. 1976 The Influence of Wind on the Surface Layer of a Stratified In 1et: Part 1: Observations. J. Phys. Oceanogr. 6, 931-940.

Hansen, D. V. \& Rattray, M. Jr, 1965 Gravitationa 1 Circulation in Straits and Estuaries. J. Mar. Res. 23. 104-121. 
Hicks, S. D. 1964 Tida 1 Wave Characteristics of Chosapeake Bay, Che sapeake Sci. 5, 103-113.

Jacobson, J. P. 1973 A Report on the Prototype Data Collected in the York, Back, Poquoson, Piankatank, Great Wicomico, and James River for the Chesapeake Bay Model Study. VIMS Spec. Rept. in App. Mar. Sci. and Ocean Eng. No. $85,44 \mathrm{p}$.

Kiley, Kevin P. 1980 The Relationship Between Wind and Current in the York River Estuary, Virginia, Apri1 1973. Masters Thesis, College of William and Mary, $195 \mathrm{p}$.

National Ocean Survey. 1972 Tidal Current Tables, 1973, Atlantic Coast of North America.

Officer, C. B. 1976 Physical Oceanography of Estuaries and Associated Coastal Vators. John Wiley and Sons, Inc., New York, 465 p.

Pritchard, D. W. 1956 The Dynamical Structure of a Coastal P1a in Estuary. J. Mar. Res, 15, 33-42.

Wang, D. P. 1979 Wind Driven Circulation in the Chesapeake Bay, Winter 1975. J. Phys. Oceanogr. 9, 564-572.

Hang, D. P. El1iott, A. J. 1978 Non-Tidal Variability in the Chesapeake Bay and Potomac River: Evidence for NonLocal Forcing. J. Phys. Oceanogr. 6, 22 5-232.

Weisberg, R. H. 1976 The Non-Tidal Flow in the Providence River of the Naragansett Bay. J. Phys. Oceanogr. 6, 721734. 